\title{
廃イオン交換樹脂からの多孔質炭素の製造
}

\author{
三浦孝一, 中川浩行, 渡邊邦夫
}

(平成10年7月28日受理, 平成10年10月16日採択)

\section{Production of Porous Carbon from Ion Exchange Resin Waste}

\author{
Kouichi Miura, Hiroyuki Nakagawa and Kunio Watanabe
}

\begin{abstract}
The possibility to produce porous carbons with controlled micropores from waste ion exchange resins was examined. Two waste ion exchange resins were used as starting materials : one was used for desalination of water (Waste-P) and the other was used for refining suger (Waste-Gel). They were carbonized at 500 to $900^{\circ} \mathrm{C}$ were nonporous due to thermal shrinkage. Waste-Gel contained about $7 \mathrm{wt} \%$ of calcium, and Waste-P adsorbed organics. Then, to clarify the effect of the impurities contained in the waste resins on the pore development, the virgin resins exchanged by calcium ion and those adsorbing phenol or fructose were prepared and carbonized. Calcium ion was found to greatly affect the carbonization behavior of the resin, and consequently prevented the resin from shrinking thermally. On the other hand, the organics adsorbed enhanced thermoplastic property of the resin. When carbonized at $900^{\circ} \mathrm{C}$, the $\mathrm{Ca}$ exchanged resin had almost same pore volume distribution as the carbonized Waste-Gel had. This clarified that the pore development of the carbonized Waste-Gel is controlled by the calcium in the resin. The porous carbons produced from the waste resins had molecular sieving property to separate carbon dioxide from methane.
\end{abstract}

KEYWORDS : Molecular Sieving Carbon, Waste Ion Exchage Resin, $\mathrm{CO}_{2} / \mathrm{CH}_{4}$ Separation

\section{1. 緒 言}

イオン交換樹脂は種々の工業において純水の製造や硬水の 軟水化に, また食品や医薬品の分野においては水質の改善な どに広く使用されている。イオン交換樹脂には, 陽イオンを 吸着する陽イオン交換樹脂と陰イオンを交換する陰イオン交 換樹脂がある。前者は酸で, 後者はアルカリで再生すること により繰り返し使用されている。機械的強度や耐薬品性に優 れるイオン交換樹脂も, 化学的な劣化や有機物等の不純物の 蓄積により次第にイオン交換能が低下する。このようにして 使用不能となった樹脂は, 廃樹脂として埋め立て処分されて いるのが現状である。しかしながら, 廃樹脂量は国内で年間 $10,000 \mathrm{~m}^{3}$ にも達し, 近年のごみ処理場不足の問題からその処 分方法が大きな問題となっている。処分方法としては, 焼却 処理も可能であるが, 焼却に際しては高濃度の煤塵や硫黄酸 化物, 窒素酸化物等の有毒ガスが発生するうえに, 発熱量が高 いために焼却炉が傷みやすいなどの問題があるため, ほとん ど実施されていないのが現状である。このような状況から, イオン交換樹脂の特性を生かした再利用法の開発が切に望ま れている。

しかし, 既往の研究としては, 廃イオン交換樹脂からほほ 市販のヤシ款系活性炭と同等の性能を持つ活性炭を製造し た例1) が見られる程度である。イオン交換樹脂から炭素質吸
着体 ${ }^{2)}$ や無機物質分散炭素3 ${ }^{3}$ を製造する特許は提出されてい るが,それらは廃樹脂を対象としていない。

本研究では, 廃イオン交換樹脂を付加価值の高い機能性材 料に転換する方法として, 廃イオン交換樹脂から均一な細孔 を持つ分子ふるい炭素 (Molecular Sieving Carbon：MSC) 製造の可能性を検討した。具体的には, 廃樹脂を炭化して 種々の炭素多孔体を調製し, それらの細孔容積分布を測定す るとともに, メタンと二酸化炭素の分離への適用性を検討し た。また, 廃イオン交換樹脂から細孔が形成される機構を炭 化時の重量変化とガスの生成挙動から検討した。

\section{2. 実 験}

\section{1 樹脂}

廃樹脂として, 糖液の精製に使用されたゲル型廃樹脂 (Waste-Gel) と脱塩用純水装置に使用されたポーラス型廃樹 脂 (Waste-P) を使用した。これらの廃樹脂の使用前の樹脂 (新樹脂) は, ともにスチレンとジビニルベンゼンの共重合体 にイオン交換基としてスルホン基を導入した強酸性陽イオ ン交換樹脂 (ゲル型: SK-1B, ポーラス型: PK228L, 三菱化 学(侏) である (Fig.1)。なお, 新樹脂には $4.80 \mathrm{~mol} / \mathrm{kg}$ のイオン 交換基が含まれている。比較のために, ゲル型およびポーラ ス型の新樹脂（SK-1B, PK228L,ともにNa型で販売されてい

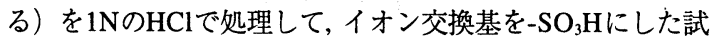




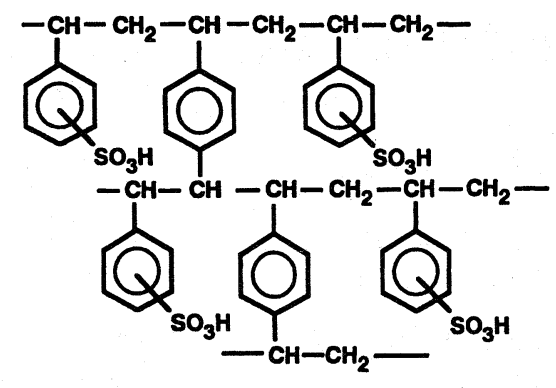

Fig.1 Chemical structure of ion exchange resin used(Gel-H).

料を調製した $(\mathrm{Gel}-\mathrm{H}, \mathrm{P}-\mathrm{H})$ 。また, 廃イオン交換樹脂に含ま れている成分の影響を検討するために, ゲル型については, カ ルシウム (Gel-Ca), 果糖 (Gel-F), ポーラス型についてはフ エノール (P-Ph) を含む試料を調製した。Gel-CaはGel-Hを $1 \mathrm{~mol} / 1$ の $\mathrm{CaCl}_{2}$ 水溶液中でイオン交換して調製した（交換 $\mathrm{Ca}$ 量 : $2.17 \mathrm{~mol} / \mathrm{kg}$ )。Gel-FはGel-Hを $2.5 \mathrm{~kg} / \mathrm{m}^{3}$ の果糖水溶液に, $\mathrm{P}-\mathrm{Ph}$ はP-Hを $37.6 \mathrm{~kg} / \mathrm{m}^{3}$ フェノール水溶液に24時間浸漬した

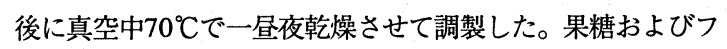
エノールの吸着量は, Gel-Fで0.1g/g-resin, P-Phで0.02g/g-resin であった。

\section{1 炭化および細孔容積分布の測定}

約 $0.5 \mathrm{~g}$ の試料をセラミックス製のボート $(14 \mathrm{mmx} 80 \mathrm{~mm}$, 深さ $10 \mathrm{~mm}$ ) にのせ, 横型のセラミックス反応管（内径 $25 \mathrm{~mm}$, 長さ $500 \mathrm{~mm})$ の中央に置き,これを, 窒素流通下 $(500 \mathrm{cc} / \mathrm{min})$ に赤外線イメージ炉 (RHL-E25P, (侏真空理工) で $10^{\circ} \mathrm{C} / \mathrm{min}$ の速度で最終温度 $\left(500 \sim 900^{\circ} \mathrm{C}\right)$ まで昇温加熱し, 最終温度 で10分間保持して炭化した。炭化した試料の細孔容積分布は 分子プローブ法によって評価した4)。すなわち, $\mathrm{CO}_{2}, \mathrm{C}_{2} \mathrm{H}_{6}, \mathrm{n}$ $\mathrm{C}_{4} \mathrm{H}_{10}$, iso- $\mathrm{C}_{4} \mathrm{H}_{10}$ の $25^{\circ} \mathrm{C}$ での吸着等温線を全自動吸着量測定装 置 (BELSORP 28, 日本ベル(㑣) で測定し, それらをDubininAstakhov式 $(\mathrm{n}=2)^{5)}$ で解析して, それぞれのガスの極限吸着 容積を求めた。そして, それらの值が各ガス分子の最小分子 径 $\left(\mathrm{CO}_{2}: 0.33 \mathrm{~nm}, \mathrm{C}_{2} \mathrm{H}_{6}: 0.40 \mathrm{~nm}, \mathrm{n}-\mathrm{C}_{4} \mathrm{H}_{10}: 0.43 \mathrm{~nm}\right.$, iso$\left.\mathrm{C}_{4} \mathrm{H}_{10}: 0.50 \mathrm{~nm}\right)$ よりも大きい細孔の容積に相当するとして 細孔容積分布を算出した。さらに, 分子ふるい能を評価する

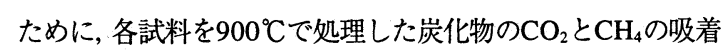
等温線を $25^{\circ} \mathrm{Cで}$ 測定した。

また, 炭化挙動と細孔形成の関連性を検討するために, 熱天 秤（TGA-50, 侏島津製作所）と質量分析計 (GCMS-QP2000, (侏)島津製作所）を直結した装置を用いて, 各試料の加熱に伴 う重量変化とガスの生成速度を連続的に測定した。

\section{3. 結果と考察}

\section{1 廃イオン交換樹脂の性状}

廃イオン交換樹脂の外観を新樹脂 (Gel-H, P-H) と比較す ると, まず色の面からはWaste-Pが濃褐色であるのに対してP-
Table 1 Ultimate Analysis and ash content of ion exchange resins used.

\begin{tabular}{lccccc}
\hline & \multicolumn{6}{c}{ Ultimate analysis [wt\% daf basis] } & Ash content \\
& $\mathrm{C}$ & $\mathrm{H}$ & $\mathrm{N}$ & $\mathrm{O}+\mathrm{S}$ (diff.) & \\
\hline Weste-Gel & 52.2 & 6.4 & 2.2 & 39.2 & 17.7 \\
\hline Weste-P & 51.6 & 7.9 & 0.6 & 39.9 & 3.1 \\
\hline Gel-H & 52.8 & 6.5 & 0 & 40.7 & 0 \\
\hline P-H & 53.2 & 6.9 & 0 & 39.9 & 0 \\
\hline
\end{tabular}

Hは不透明な白みがかった褐色であり, 明暸な違いが見られ た。また, Gel-Hが透明な褐色であるのに対してWaste-Gelの 色はやや白みがかった褐色であった。形状はいずれも直径約 $0.5 \mathrm{~mm}$ の真球状であり, 廃樹脂には繰り返し使用による粒子 の磨耗や欠損はほとんど見られなかった。

Table 1 に $70^{\circ} \mathrm{C}$ で真空乾燥した後の廃イオン交換樹脂と新 樹脂の元素分析値と兏分含有量を示す。廃イオン交換樹脂 には若干量の窒素が含まれているが, 他の元素分析値は新樹 脂と大差なく, 廃イオン交換樹脂は新樹脂と比較して構造的 に大きくは変化していないと考えられる。一方灰分を比較 すると, Waste-Gelのみに多量の灰分が含まれていることが わかる。Waste-Gelを酸化溶解して, 原子吸光光度計 (AA660，(侏島津製作所）によって含有金属を同定したところ，そ のほとんどがCaであり,その含有量は7.60wt％であった。

\section{2 炭化後の試料の形状}

各試料を $900^{\circ} \mathrm{C}$ で炭化し, 得られた炭化樹脂の形状を比較 した。有機物を吸着させたGel-F, P-Phはフレーク状で炭化時 にいったん溶融・液相炭化したと考えられるのに対し, 廃イ オン交換樹脂およびCaをイオン交換した樹脂はいずれも球 形を保ったままで, かつ非常に固く, 固相炭化したことを示し ている。H型であるGel-H, P-Hはかろうじで球形を保ってい たが,かなり脆く手で触れると容易に壊れた。本研究では, 廃 イオン交換樹脂の炭化物を吸着剤等に用いることを想定して いるが, 廃樹脂の炭化物が球形を保っている上に非常に固い ということは, 工業的に非常に大きなメリットである。この ように, 試料により炭化後の形状に大きな差が見られたので, 炭化挙動も試料により異なっているものと考えられる。以 下, 炭化時の重量変化, ガスの生成速度, 細孔構造の変化につ いて詳細に検討する。

\section{3 炭化に伴う重量の変化}

Fig.2に各樹脂の炭化に伴う重量変化を示す。ゲル型の樹 脂について見ると, Gel-Hは $300^{\circ} \mathrm{C}$ 付近と $400^{\circ} \mathrm{C}$ 付近で大きく 重量が減少し，二段階的に分解していることがわかる。それ に対L, Waste-Gelは $400 \sim 450^{\circ} \mathrm{C}, 500 \sim 550^{\circ} \mathrm{C}, 700 \sim 750^{\circ} \mathrm{C} の$ 温度域でやや急激な重量減少が見られるものの, 全体として 徐々に分解している。また, $900^{\circ} \mathrm{C} に$ 扔ける固体収率は, Gel-H が0.42であるのに対してWaste-Gelは0.59と, 大きく異なって

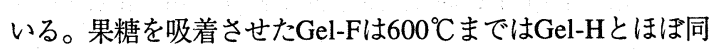




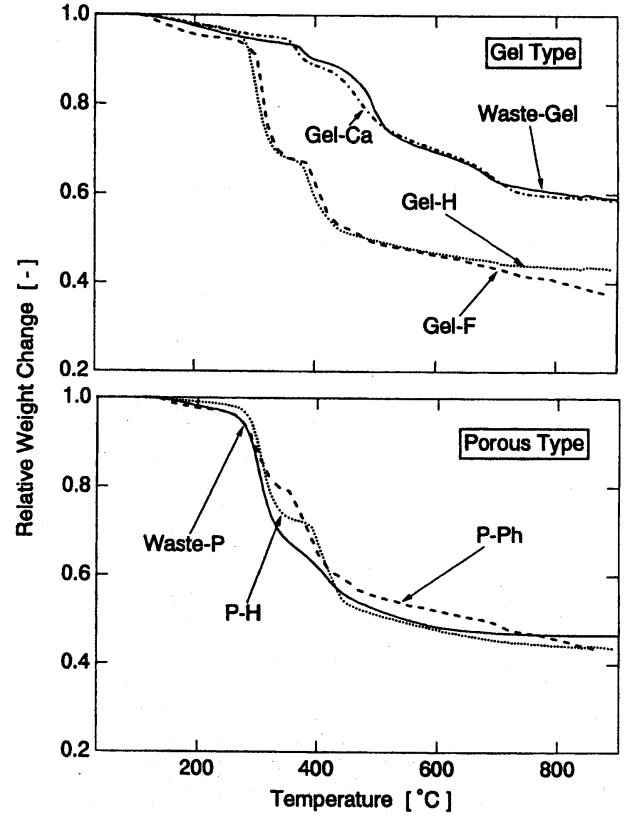

Fig.2 Comparison of weight decreasing curves during carbonizasion between waste resins and virgin resins with various treatment.

ビように重量が減少していくが, $600^{\circ} \mathrm{C}$ 以上ではGel-Fの方が

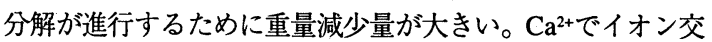
換したGel-Caの重量変化挙動は, Gel-Hとは大きく異なり, Waste-Gel とほほ同様の挙動を示した。また両者の $9000^{\circ} \mathrm{Cにお}$ ける固体収率もほほ同じであった。これらの結果とWaste-Gel に多量のCaが含まれていたことから, Waste-Gelの熱分解挙動 がその新樹脂のGel-Hと大きく異なるのは, Waste-Gel中に含 まれるイオン交換性のCaの影響によるものと考えられた。

ポーラス型の樹脂について見ると, P-Hの重量減少の様子 はGel-Hとほほ同じで, 二段階的に熱分解が進行しているの に対し, Waste-Pの $300^{\circ} \mathrm{C}$ 付近の重量減少の様子はP-Hとほほ 同じであるが, 二段階目の重量減少はGel-Hほど顕著ではな い。500ํ以上の両者の重量変化の挙動は大きな違いはない

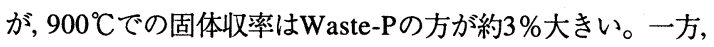
フェノールを吸着させたP-Phは, 二段階的に熱分解している が, 一段階目の重量減少量はP-Hほど大きくなく, Gel-Fと同 じよjに $500^{\circ} \mathrm{C}$ 以上での重量減少量が大きい。以上のように, イオン交換樹脂の熱分解挙動は, 交換イオン種や樹脂内に吸 着した有機物に大きく影響されることが明らかとなった。

\section{4 炭化に伴うガス成分の生成速度}

Fig.3に, 各樹脂の炭化に伴うガス成分の生成速度を示す。 新樹脂のGel-HとP-Hのガスの生成パターンはほほ同じであ った。主生成ガスは $\mathrm{H}_{2} \mathrm{O}$ と $\mathrm{SO}_{2}$ で, $300^{\circ} \mathrm{C}$ 付近に $\mathrm{H}_{2} \mathrm{O}$ と $\mathrm{SO}_{2}$ の 生成ピークがあり,さらに $450^{\circ} \mathrm{C}$ 付近に $\mathrm{H}_{2} \mathrm{O}$ の生成ピークがあ ることがわかる。これらの温度域はともに重量減少か影著で
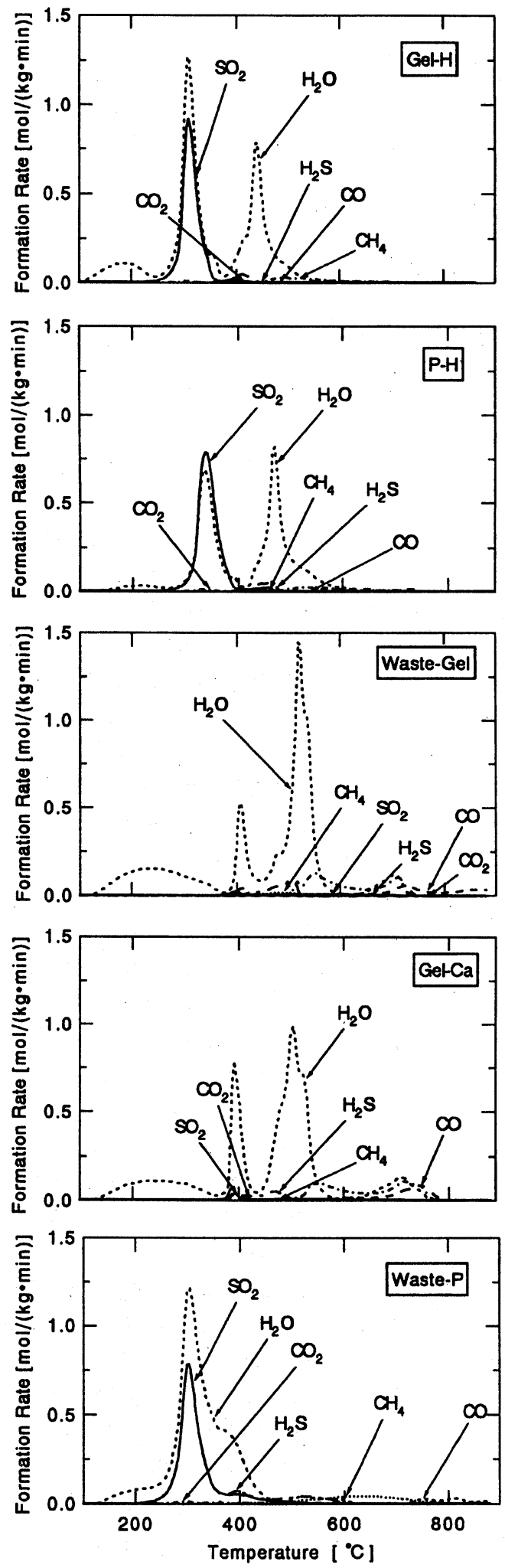

Fig.3 Gas formation rates during carbonization of resins. 
あつた温度域である ( Fi g. 2)。イオン交換樹脂の構造から判 断して,H2Oと SO2は官能基であるスルホン基の分解によって 生成したと考えられる。400ㄷ までにガスとして生成したHRO

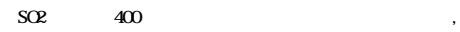
$400^{\circ} \mathrm{C}$ まではスルホン) 基の分解のみがおこっていることを示 唆している。なお, $400^{\circ} \mathrm{C}$ までに生成したSO2の量はGel - Hで 3. 41mm / kg, P- Hで3. 30ndl/kgであり, 樹脂中に含まれるスル ホン基の量がともに4. 80ndl/kgであることを考えると,少なく とも約70\%のスルホン基が400ㄷ までに分解したことになる。 Gel - Hの廃樹脂であるU bist e- Gel のガス成分の生成挙動は Gel - Hとは大きく異なり, 主ガス生成物はH2Oのみであり, SO2 はほとんど生成しなかった。また, H2Oの生成プロファイル はGel-Hのものとは大きく異なり, $400^{\circ} \mathrm{C}$ と $520^{\circ} \mathrm{C}$ 付近に生成 ピークが存在した。W Whste-Gel にはCaが多く含まれていたの で, SO2の生成が大きく抑制されたのは官能基の分解時にCaS もしくはCaSO4が生成したためと推測される。この推測の妥 当性を確かめるために, Ca2+でイオン交換したGel - Caのガス 成分の生成速度を検討すると, Whst e - Gel と同様主生成ガスは HROのみであり,さらにH20の2つの生成ピークの温度域も Wáste-Gelの弚れらとほぼ一致している。先の重量変化曲線 において, 900Cでの固体収率がGel - Hと比較してGe1-Caは非 常に高かったがGel - Ca中に含まれるCaの重量を除いて考え ると, Ge1-Caの固体収率の増加分は生成したH2OとSO2の重量 の差とほぼ同じであった。このことは,樹脂中のCaによる炭 化挙動の大きな变化は, 主に官能基の分解挙動の違いによる ところが大きいということを示している。

ポーラス型の廃樹脂であるWast e-Pのガス成分の生成挙動 もP-Hとは大きな違いが見られた。主生成ガスはP-Hと同樣 H2Oと $502 て ゙, 300^{\circ} \mathrm{C}$ 付近の光れらの生成ピークはP-Hとほぼ 同じであるがP- Hの $450^{\circ} \mathrm{C}$ 付近に見られたHROの生成ピーク が見られない。H2OとSO2の生成量をP-Hと比較すると, P- H

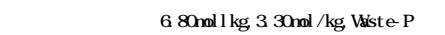
いては10. 5mol / kg, 3. 8ndl l kgであり,ともに廃樹脂の方が多 かった。このように,廃イオン交換樹脂と新樹脂の熱分解機 構は大きく異なることが明らかになった。

3.5 炭化に伴う細孔構造の変化

Fi g. 4に, 廃イオン交換樹脂( Wast e- Gel , Wast e-P) と光れ らの使用前の樹脂である新樹脂から調製した各樹脂を $600^{\circ} \mathrm{C}$ と $900^{\circ} \mathrm{C} て ゙$ 炭化した試料の累積細孔容積分布を示す。まず, 廃 イオン交換樹脂と新樹脂の炭化物の細孔容積分布を比較する

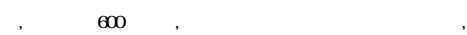
ゲル型, ポーラス型ともに廃樹脂と新樹脂の炭化物は0.4

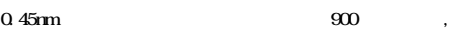
樹脂と新樹脂の間では大きな差か現れた。全細孔容積は, 廃

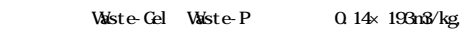
0. 21× 10-3mB阪gで, 細孔が発達しているのに対し, 新樹脂の Gel - H, P- Hはともに非常に小さく, ほとんど細孔が存在して

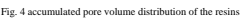

carbonized at 600t and 900:ב̌.

おらず,細孔が熱によって収縮したことを示している。細孔 径分布についてはVAst e-Gel は0.38〜0.43nmに集中したシャ ープな分布を持っており, Wast e-PはVhast e- Geはりはブロー ドであるが細孔の大部分が0. 35〜0. 45nm集中している。市 販のMSCであるCommerci al MSCと比較すると,いずれの廃 イオン交換樹脂炭化物の細孔径分布も平均細孔径はやや大き いものの同程度のシャープな分布であり, 廃イオン交換樹脂 の $900^{\circ} \mathrm{C}$ 炭化物がNSCとして利用できることが期待できる。 次に, 有機物およびCaが炭化物の細孔容積分布に与える影

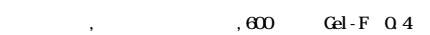


0.45nm, P-Phで0.4 0.5nmの細孔が発達していたが, $900^{\circ} \mathrm{Cに}$ なるとともにほとんど細孔が存在しておらず, Gel-H , P-Hと

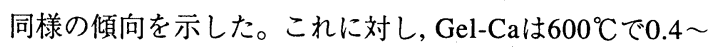
$0.45 \mathrm{~nm}, 900^{\circ} \mathrm{C} て ゙ 0.35 \sim 0.45 \mathrm{~nm}$ の細孔が発達しており, WasteGel と細孔容積分布が非常に類似している。先の重量変化, ガ スの生成速度と考えあわせると, Waste-Gel $9900^{\circ} \mathrm{C}$ 炭化物の 細孔容積分布が非常にシャープであったのは, 樹脂中に存在 しているイオン交換性のCaが樹脂の炭化挙動に大きく影響 を与え, 細孔の形成・維持に大きく寄与しているためと考え られる。ここには示してないが, プロトン交換前のNa型の樹 脂を炭化すると, 樹脂は完全に溶融し, $900^{\circ} \mathrm{C}$ 炭化物には細孔 がほとんど存在しなかった。これらの結果から, Waste-Gelと Gel-Caでは, 2価であるCaが官能基とイオン架橋を形成して いるため, 炭化時に樹脂が溶融するのが抑制され, その結果細 孔が形成したものと考えられる。Gel-Ca炭化物の細孔生成の 機構については続報でより詳細に検討する。

次に, Waste-Pの炭化物の細孔形成の機構について考察す る。まず, Waste-Pには3wt\%の灰分が含まれていたが, 塩酸 で処理して扊分を除いた試料の炭化物はWaste-Pの炭化物と ほほ同じ細孔容積分布を持っていたので, 灰分は細孔の形成 には寄与していないといえる。熱重量変化（Fig.2）とガス 分析の結果 (Fig.3) から, Waste-Pは $300^{\circ} \mathrm{C}$ 付近で新樹脂と同 様に官能基が分解するが, 新樹脂に見られた $450^{\circ} \mathrm{C}$ 付近の $\mathrm{H}_{2} \mathrm{O}$ の生成ピークが見られなかった。Waste-Pのイオン交換容量 を測定したところ, 新樹脂（P-H）の90\%以上あり, 官能基は ほとんど変質していなかった。先に述べたように, 元素分析 值も窒素がごく少量含まれている以外は新樹脂であるP-Hと ほほ同じであった。このようにWaste-PとP-Hの構造には大 きな相違がみられなかったが, Waste-Pでは一部の官能基が架 橋しているなどP-Hとはわずかに構造が異なると考えられ る。そのため, Waste-Pの熱分解機構はP-Hのそれとは異なり, その結果として両者の炭化物の細孔構造に大きな違いが生ま れたものと考えられる。

\section{6 廃イオン交換樹脂のメタンと二酸化炭素の吸着特性}

Waste-Gel, Waste-Pの $900^{\circ} \mathrm{C}$ 炭化物の吸着特性の一例とし

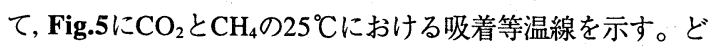
ちらの炭化物も, $\mathrm{CO}_{2}$ と比較して $\mathrm{CH}_{4}$ の平衡吸着量が非常に少 ないことがわかる。 $700 \mathrm{mmHg}$ での ( $\mathrm{CO}_{2}$ の吸着量) $/\left(\mathrm{CH}_{4}\right.$ の吸着量) の值は, Waste-Gelで5.7, Waste-Pで6.1であり, 両 炭化物が $\mathrm{CO}_{2}$ と $\mathrm{CH}_{4}$ を分離する吸着剤として利用できること を示唆している。このように, 廃イオン交換樹脂から分子ふ るい炭素を製造できることがわかった。

\section{4. 結 言}

廃イオン交換樹脂を高機能な材料に転換する方法として, 廃イオン交換樹脂から均一な細孔を持つ分子ふるい炭素の製

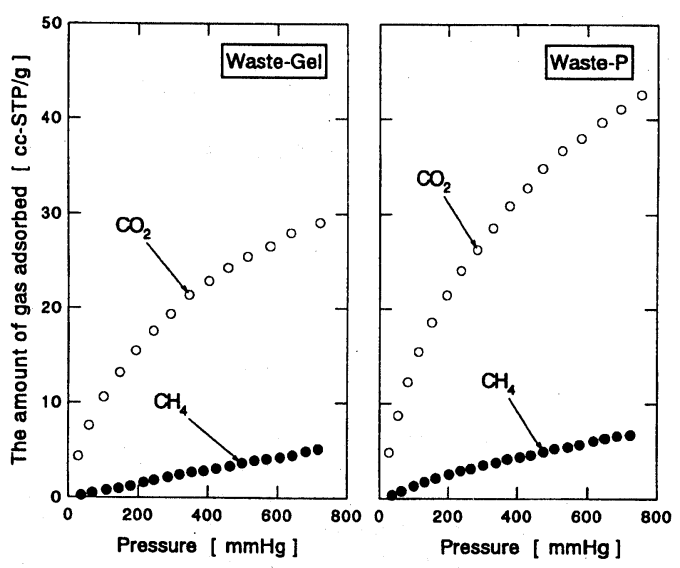

Fig.5 Uptake of $\mathrm{CO}_{2}$ and $\mathrm{CH}_{4}$ on the carbonized waste resins. $\left(\mathrm{T}_{\mathrm{f}}=900^{\circ} \mathrm{C}\right)$

造を試みた結果, 二種類の廃イオン交換樹脂を $900{ }^{\circ} \mathrm{C} て ゙$ 炭化す ることによって, 新樹脂の炭化物には存在しない 0.35 $0.45 \mathrm{~nm}$ の細孔を持つ多孔質炭素を製造することができた。 このようにして製造した多孔質炭素の $\mathrm{CH}_{4}$ と $\mathrm{CO}_{2}$ の $25^{\circ} \mathrm{C}$ の吸 着等温線を測定したところ, $\mathrm{CH}_{4}$ と比較して $\mathrm{CO}_{2}$ が非常に多く 吸着し, $\mathrm{CH}_{4}-\mathrm{CO}_{2}$ の分離吸着剂として十分適用できることが わかった。しかも廃樹脂の炭化物は, もとの球形を保ってい るうえに非常に硬く, そのまま吸着剤や触媒に用いることが できるという工業的なメリットを持っている。

新樹脂と廃樹脂の炭化に伴う細孔構造の変化を追跡したと ころ, 新樹脂は $900^{\circ} \mathrm{C} て ゙$ 炭化すると細孔が収縮してつぶれてし まうのに対し, 廃樹脂は $900^{\circ} \mathrm{C} て ゙ も$ 細孔を保持していることが わかった。その原因を明らかにするために, 樹脂の炭化挙動を 検討したところ, 糖の精製で使用された廃樹脂は樹脂中に含ま れているCaによって炭化挙動が大きく変化し, その結果とし て細孔が保持されていることがわかった。純水装置で使用さ れた廃樹脂は, 樹脂中に含まれている灰分ではなく, 一部の官 能基が架橋しているなどのわずかな構造の変化によって熱分 解機構が変化し, 細孔が保持されているものと推定された。

\section{謝 辞}

本研究の一部は, 文部省科学研究費補助金の特定領域研究 A(カーボンアロイ)により行った。ここに感謝の意を表しま す。(課題番号：09243227)

\section{文 献}

1）本多一秀, 瀬能 衛, 落合康伸, 柴田彰久, 野崎誠夫, 第4 回廃棄物学会講演論文集 (1993) 285-288.

2) 山本 桂, 特開昭 49-53594 (1974).

3）原田紘一, 村上喜昭, 特公昭 58-13488（1983）

4) T.G. Lamond, J.E. Metcalfe, III and P.L. Walker Jr., Carbon 3 (1965) 59-63.

5) Astakhov, V.A., M.M. Dubinin and P.G. Romankov, Theor. Osn. Khim. 3 (1969) 292-297. 